\title{
Impact of the Iraq Marshlands Restoration Program on Livestock Population and Production in the Southern Marshes of Iraq
}

\author{
Asaad Y. Ayied ${ }^{1, *}$ and Peter Reiss ${ }^{2}$ \\ ${ }^{1}$ Animal Production Department, College of Agriculture, University of Basra, Basra, Iraq \\ ${ }^{2}$ Development Alternatives, Inc., Bethesda MD 20895, USA
}

\begin{abstract}
The USAID Iraq Marshlands Restoration Program (IMRP) promoted the application of two promising initiatives tested from 2004 to 2006: (1) the introduction of alfalfa and maize fodder to feed and improve the nutrition of buffalo and (2) the creation of a veterinary service to increase livestock production and health. The livestock sector in the marshlands has seen dramatic improvement since IMRP ended in 2006. These changes are across the board in the absolute number of livestock (from 66,700 heads in 2006 to 111,525 heads in 2017) and in their increasing diversity (buffalo were $74.33 \%$ of all livestock in 2006 but decreased to $70.33 \%$ in 2017). Buffalo, specifically, had greater birth weight (40 kg in 2006 and $45.6 \mathrm{~kg}$ in 2017), greater daily growth rates $(0.3 \mathrm{~kg}$ in 2006 and $1-1.25 \mathrm{~kg}$ in 2017), higher daily milk yields (8.81 kg/day in 2006 and $9.69 \mathrm{~kg} /$ day in 2017), and longer lactation periods (150 days in 2006 and 238 days in 2017). There have been accompanying advances in the closely related meat and dairy markets. Live weight and market prices for buffalo and cattle have increased three- to four-fold. Rising daily milk yields also sparked the creation of cottage industries to produce dairy products using higher fat buffalo milk. These changes all point to an increasingly healthy and dynamic livestock sector in the marshlands. However, other anticipated changes in the marshlands did not meet expectations. In 2006, IMRP predicted a strong shift away from the historical dominance of buffalo ownership to a more diversified pattern of ownership that included the relatively newly introduced cattle and a rapid increase in sheep holdings, making the latter the dominate animal. Instead, buffaloes have continued to be the vastly most numerous animals owned in the marshlands. In 2017 , they ranged from 65 to $75 \%$ of all livestock holdings. Greater access to reflooded marshes by buffalo herders and increased financial earnings realized from meat and dairy production may help to explain the continued reliance on buffalo ownership. IMRP's introduction of a veterinary service dedicated to working in the marshlands villages was far less successful but highly regarded by Marsh Arabs, being the first time that the services were offered in the marshes.
\end{abstract}

Keywords: Marshland, Iraq, Buffalo, diversity, Performance.

\section{INTRODUCTION}

Several factors have caused the decline and deterioration of the buffalo population in Iraq's marshes, with the first Gulf War, the consequent economic blockade and the removal of supports on feed for breeders playing a major role [1]. The main cause was the systematic drainage of the marshes, which had a disastrous impact on life in the marshes [2]. A study of Iraq's Ministry of Agriculture [3] indicated that the number of buffalo decreased by $57.3 \%$ from 150,000 in 1990 to 64,000 in 1999 . That change is associated with a drastic decline in production [4]. Buffalo population is distributed as follows: $6.8 \%$ in the north, $41.0 \%$ in central Iraq and $52.2 \%$ in the south. Buffaloes are mostly bred $(98 \%)$ as low input production systems [5].

The U.S. Agency for International Development (USAID) [6] found that production, animal health, dairy processing, and marketing were all poor, as the local population, commonly called Marsh Arabs, adjusted to their newly imposed conditions. The main reasons for

*Address correspondence to this author at the Animal Production Department, College of Agriculture, University of Basra, Basra, Iraq;

Tel: 00964 7801009823; E-mail: asaad.yheia@gmail.com

ISSN: 1927-5196 / E-ISSN: 1927-520X/19 the poor performance of this livestock sector were inadequate feed supply for the animals and the consequent poor body condition [7], unreliable and/or inaccessible veterinary services [8], poor collection and processing services, and inaccessible market infrastructure.

The 2006 USAID Iraq Marshlands Restoration Program (IMRP) assessment of the sector revealed that buffaloes and their dairy production required immediate attention and improvement. Issues related to processing and marketing could be addressed once production levels increased. IMRP attempted to revitalize buffalo farming and dairy production in the marshlands by focusing on two of the most promising initiatives: (1) introducing and encouraging the cultivation of alfalfa and sorghum to improve animal health and nutrition and increase birth rates and (2) initiating a veterinary service for recently graduated veterinarians to improve access to veterinary services and provide meaningful employment to unemployed and under-utilized young professionals in the livestock sector.

In 2006, IMRP identified what it is called a "dramatic shift" in livestock populations in the marshes from water buffalo to sheep herding, which largely coincided with 
the drainage of the marshes. With the displacement of most of the indigenous people into drained areas between 1980 and 1992, animal owners could not care for their buffaloes. Water buffalo numbers decreased to low levels throughout the area, except for inside Hammar Marsh, beyond Garmit Beni Said, where small communities of Marsh Arabs lived traditionally on islands where they kept farming a high number of water buffalo.

Interviews with marsh dwellers suggested that about half of the families in Huwaizah and Hammar marshes and two-thirds of those in Nahr Al-Aaz owned buffaloes, but the number of animals were small. Families with water buffaloes generally had four animals in Nahr Al-Aaz, two in Huwaizah, and one in Hammar. Otherwise, farmers kept Arabi breed sheep and cattle which were a cross between Friesian and $\mathrm{Al}$ Jenoubi (literally, "southern") breeds, thus well adapted to the local climate with higher milk production.
The main objectives of the present study were to evaluate the effects of two of the most promising initiatives from IMRP: feeding and nutrition of buffaloes by introducing alfalfa and maize fodder, and providing a veterinary service to support buffalo farming and promote production and health.

\section{MATERIALS AND METHODS}

The number of animals and their species were collected from data kept by the departments of the Ministry of Agriculture in Basrah, Maysan and Dhi-Qar governorates.

The 2018 study chose areas adjacent to the marshlands known for agricultural production and livestock breeding (Table 1 and Figure 1). Samples of milk were recorded weekly by the staff of agriculture department in the three districts. We selected only the full and complete records from 2012-2017 of the number of buffalo shown in Table 1 . The total number

Table 1: Study Sites

\begin{tabular}{|c|c|c|c|}
\hline & Sites & Number of Herds & Number of Buffalo \\
\hline 1 & Maysan Governorate / Huwaizah Marsh & 103 & 400 \\
\hline 2 & Al Mejar District / Qal'at Saleh District, Huwaizah & 95 & 127 \\
\hline 3 & Al Mejar District / Qal'at Saleh District, Huwaizah & 89 & 99 \\
\hline 4 & Dhi-Qar Governorate / Al Chebayish / Hammar Marsh & 122 & 252 \\
\hline 5 & Al Chebayish / Central Marsh & 90 & 203 \\
\hline 6 & Al Adil Sub-district / Uoda Marsh/ Central Marsh & 76 & 98 \\
\hline 7 & Qurna / Central Marsh & 132 & 356 \\
\hline \multicolumn{2}{|r|}{ Total } & 604 & 1535 \\
\hline
\end{tabular}

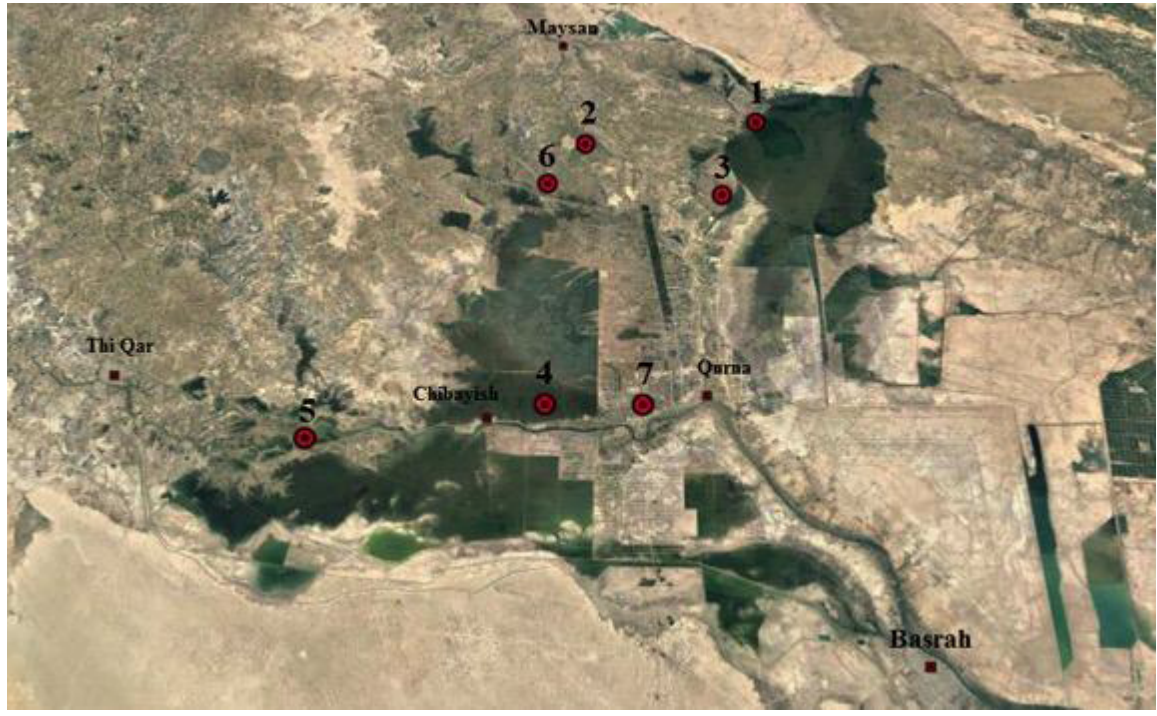

Figure 1: Study Sites map, as Shown in Table 1. 
of animals was 1,535 milking buffaloes with 9,210 milking records. These data were used to calculate the daily milk yield, total annual milk yield and lactation period (total annual milk yield was equal to daily milk yield times lactation period of each animal).

In addition, we used detailed structured questionnaires to collect information from 103 buffalo owners (987 milking buffaloes and their calves) from the buffalo breeding areas during continous visits by the impact assessment team. All cattle and sheep breeders were included in the survey. For cattle, the total number of milking cows and calves was 156 . We also included, six, four, and five sheep herds in this survey from Maysan, Basrah and Dhi-Qar, respectively. Sheep and their lambs numbered 215 head. The questionnaires included the total number of animals, number of milking animals, daily milk yield, number of milking/day, birth weight, calf gender, type and quatity of available feed, feed consumption. These quationnaires were done to assess and verify the accuracy of the agriculture department records.

Mean birth weight was calculated from the above data collected through our questionnaires. We recorded weights from several slaughterhouses within each studied districts during 2018. The number of slaughtered buffalo, cattle, calves and lambs was 420 , 235 and 612, respectively. The daily growth rate of buffalo, cattle, and sheep was calculated as the difference between market weight and birth weight divided by the age at slaughter. The range of age at marketing was 8-10 for buffalo, 10-12 for cattle, and 69 months for sheep.

\section{RESULTS AND DISCUSSION}

\section{Livestock Diversity}

Buffalo continue to be the most numerous animals reared in the marshlands in all three governorates. In 2017 , they ranged from 65 to $75 \%$ of all animal holdings. And while those percentages have somewhat decreased since 2006, the actual number of buffaloes has increased by as much as 17,000 head. In fact, the number of all animals, including cattle, sheep, and goats, has increased.

Table 2 displays the number of each livestock in marshland areas in Basra governorate. It shows a steady increase in all of the animals. It also confirms the continued dominance of water buffalo ownership by the local inhabitants.

However, the percentage of buffalo in Basra decreased from 2016 to 2017, although their total number increased by roughly 10,000 . There has been a decided shift to cattle ownership. Both buffalo and cattle consume the same feed and in roughly similar quantity, but cattle do not need period of time in the water, as buffalo do and produce more milk, especially when local cattle are crossed with Holstein.

Table 3 shows the number of livestock in the DhiQar governorate marshlands over more than a decade. Buffaloes had the largest percentage of the total population, which fluctuated from $66 \%$ in 2013 to $76 \%$ from 2014 to 2017 . There was a sharp increase in buffalo holdings from 2014. It is likely related to the

Table 2: Livestock in the Marshlands of Basra Governorate

\begin{tabular}{|c|c|c|c|c|c|c|}
\hline \multirow{2}{*}{ Year } & \multicolumn{5}{|c|}{ Number of Livestock Owned } & \multirow{2}{*}{$\begin{array}{c}\text { Buffalo as Part of } \\
\text { Total }\end{array}$} \\
\hline & Buffalo & Cattle & Sheep & Goats & Total & \\
\hline 2006 & 41200 & 11650 & 1200 & 195 & 54245 & $76 \%$ \\
\hline 2007 & 42000 & 12000 & 1500 & 220 & 55720 & $75 \%$ \\
\hline 2008 & 42350 & 12500 & 2200 & 350 & 57400 & $74 \%$ \\
\hline 2009 & 43982 & 13000 & 2600 & 300 & 59882 & $73 \%$ \\
\hline 2010 & 44310 & 13800 & 2610 & 350 & 61070 & $73 \%$ \\
\hline 2011 & 46400 & 14300 & 3000 & 350 & 64050 & $72 \%$ \\
\hline 2012 & 46870 & 15000 & 4000 & 390 & 66260 & $71 \%$ \\
\hline 2013 & 47462 & 15900 & 4651 & 400 & 68413 & $69 \%$ \\
\hline 2014 & 48579 & 16280 & 6000 & 560 & 71419 & $68 \%$ \\
\hline 2015 & 49762 & 17450 & 4000 & 400 & 71612 & $69 \%$ \\
\hline 2016 & 50000 & 18000 & 4000 & 400 & 72400 & $69 \%$ \\
\hline 2017 & 51199 & 18528 & 8484 & 666 & 78877 & $65 \%$ \\
\hline
\end{tabular}


Table 3: Livestock in the Marshlands of Dhi-Qar Governorate

\begin{tabular}{|l|c|c|c|c|c|c|}
\hline \multirow{2}{*}{ Year } & \multicolumn{3}{|c|}{ Number of Livestock Owned } & \multirow{2}{*}{ Total } & \multirow{2}{*}{ Buffalo as Part of Total } \\
\cline { 2 - 6 } & Buffalo & Cattle & Sheep & Goats & & $71 \%$ \\
\hline \hline 2006 & 8000 & 2000 & 1000 & 200 & 11200 & $70 \%$ \\
\hline 2007 & 10000 & 2500 & 1500 & 250 & 14250 & $67 \%$ \\
\hline 2008 & 10300 & 2800 & 2000 & 300 & 15400 & $68 \%$ \\
\hline 2009 & 11000 & 3000 & 2000 & 300 & 16300 & $67 \%$ \\
\hline 2010 & 13000 & 3500 & 2500 & 350 & 19350 & $69 \%$ \\
\hline 2011 & 16000 & 4000 & 3000 & 350 & 23350 & $69 \%$ \\
\hline 2012 & 16000 & 4000 & 3000 & 350 & 23350 & $66 \%$ \\
\hline 2013 & 16500 & 4500 & 3500 & 400 & 24900 & $76 \%$ \\
\hline 2014 & 26000 & 4000 & 4000 & 400 & 34400 & $76 \%$ \\
\hline 2015 & 26000 & 4000 & 4000 & 400 & 34400 & $76 \%$ \\
\hline 2016 & 26000 & 4000 & 4000 & 400 & 34400 & $76 \%$ \\
\hline 2017 & 26000 & 4000 & 4000 & 400 & 34400 & \\
\hline
\end{tabular}

good water availability in the marshes of that governorate.

A number of different livestock in Maysan governorate is shown in the Table 4. Here, the total number of livestock increased by $113 \%$ from 2006 to 2017 , and buffalo ownership roughy doubled as well.

Among the three southern governorates that have marshlands, Basra has a larger number of animals than Dhi-Qar and Maysan. A total number of livestock in Basra was nearly 79,000 head in 2017, and in DhiQar and Maysan 40,000 and 25,000, respectively. We were surprised to learn that the number of buffalos has remained so large in the marshlands, despite water quality and water quantity issues. In 2006, we did not expect that it would be the case

The percentage of buffaloes in the three governorates is shown in Figure 2. Both Basra and Maysan had a decline in buffalo percentage from 2006 to 2017. In comparison, Dhi-Qar shows a sharp increase in 2014 that held steady through 2017 . The main reason is likely the quantity and quality of water in Dhi-Qar marshes in comparison with marshes in Basra and Maysan.

Table 4: Livestock in the Marshlands of Maysan Governorate

\begin{tabular}{|l|l|l|l|l|l|l|}
\hline \multirow{2}{*}{ Year } & \multicolumn{3}{|c|}{ Number of Livestock Owned } & \multirow{2}{*}{ Total } & \multirow{2}{*}{ Buffalo as Portion of Total } \\
\cline { 2 - 6 } & Buffalo & Cattle & Sheep & Goats & \\
\hline \hline 2006 & 17500 & 2200 & 1123 & 300 & 23129 & $76 \%$ \\
\hline 2007 & 18750 & 2589 & 1350 & 350 & 25046 & $75 \%$ \\
\hline 2008 & 20100 & 2983 & 1900 & 450 & 27441 & $73 \%$ \\
\hline 2009 & 21800 & 4000 & 2000 & 450 & 30259 & $72 \%$ \\
\hline 2010 & 23200 & 4500 & 2478 & 550 & 32738 & $71 \%$ \\
\hline 2011 & 25720 & 5000 & 3000 & 650 & 36381 & $71 \%$ \\
\hline 2012 & 26736 & 5000 & 3000 & 650 & 37398 & $72 \%$ \\
\hline 2013 & 28500 & 5500 & 3100 & 700 & 39813 & $71 \%$ \\
\hline 2014 & 30000 & 6000 & 3120 & 700 & 41834 & $71 \%$ \\
\hline 2015 & 31988 & 6500 & 3600 & 750 & 44853 & $71 \%$ \\
\hline 2016 & 33651 & 7000 & 4000 & 800 & 4767 & $70 \%$ \\
\hline 2017 & 34320 & 7591 & 4432 & 820 & 49180 & 7 \\
\hline
\end{tabular}




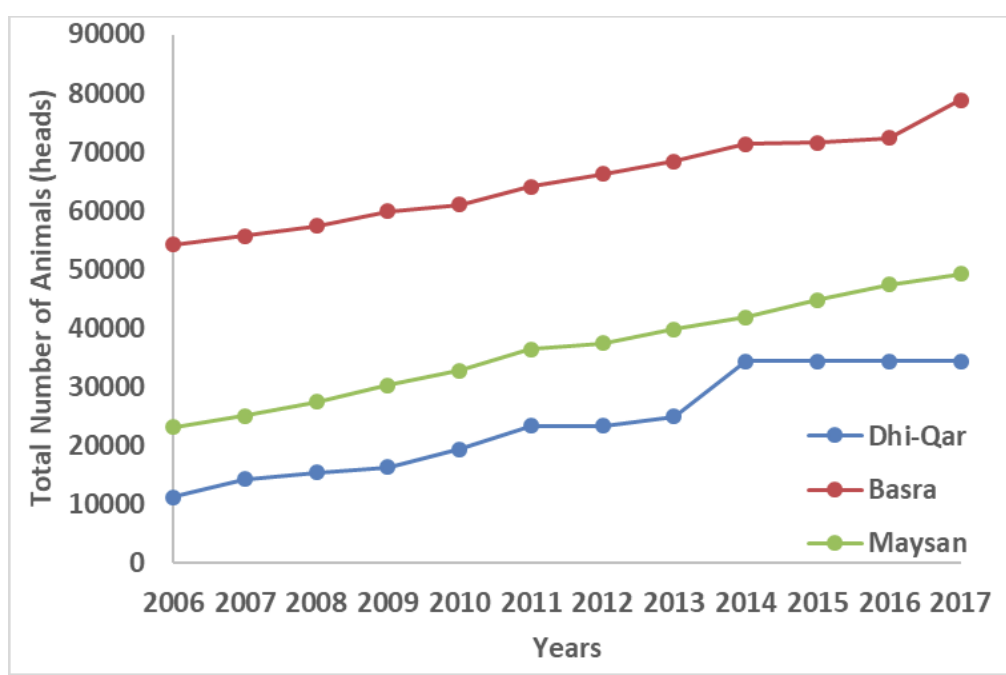

Figure 2: Total Number of Animals in Three Southern Governorates.

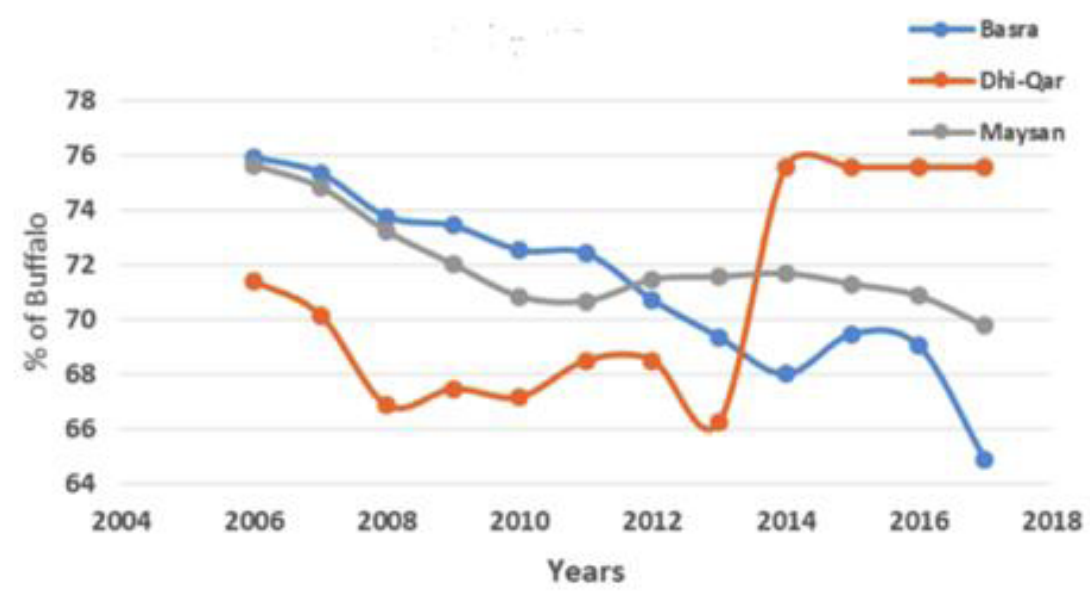

Figure 3: Percent of Buffalo in Different Governorates.

\section{Reproduction and Calf Performance}

Considerable research has confirmed the relationship between protein nutrition on one hand and the reproduction, pregnancy and lactation of livestock on the other, particularly consuming high protein legumes like alfalfa. High protein diets stimulate live weight gain or reduce live weight loss [9], while increasing ovulation rates [10], placental size [11], birth weight [12] and survival [13]. The increased birth weight possibly lowers the incidence of retained placenta, while milk yield and milk production efficiency are increased [14]. Protein deficiency in early life also prevents the stunting of final body size in adulthood [15].

In general, the number of calves born during the lifetime of a buffalo cow in the marshlands has increased with improvements related to to alfalfa and sorghum cultivation. The calving interval for buffalo, which has been historically high at 450 days, is shorter despite the harsh environment, poor feed supply, high temperatures, and degraded water quality. There has also been an increase in the health and growth rate of calves, especially during their first months due to the increased volume of milk that the calf can suck.

A comparison of livestock birth weight, daily growth rate, and meat prices in 2006 and 2018 (Tables 5 and 6) reveals that nearly all of these key indicators of the livestock sector have increased significantly over the 12 years. Alfalfa has become a common staple of the diet and even bran and straw have increased, stimulating greater birth weight and higher daily growth.

The net profit realized from a kilogram of live weight were ID 1,275 (USD .87), for buffalo, ID 1,166 (USD .79) for cattle and sheep are and ID 1,674 (USD 1.10) for sheep. 
Table 5: Livestock Live Weight, Growth Rate, and Meat Prices in 2006 (kilogram / Iraqi dinar) (IMRP, 2006)

\begin{tabular}{|c|c|c|c|c|c|c|c|}
\hline \multirow{2}{*}{ Animal } & \multirow{2}{*}{$\begin{array}{c}\text { Birth } \\
\text { Weight }(\mathbf{k g})\end{array}$} & \multirow{2}{*}{$\begin{array}{l}\text { Daily Growth } \\
\text { Rate (kg) }\end{array}$} & \multicolumn{2}{|c|}{$\begin{array}{l}\text { Daily Feed Consumption } \\
\text { (kg) }\end{array}$} & \multirow{2}{*}{ Market Weight (kg) } & \multirow{2}{*}{$\begin{array}{l}\text { Price of Live } \\
\text { Weight (kg) }\end{array}$} & \multirow{2}{*}{$\begin{array}{l}\text { Meat Price } \\
\quad \text { (ID/kg) }\end{array}$} \\
\hline & & & Bran & Straw & & & \\
\hline Buffalo & 40 & 0.3 & 2 & 4 & 149.5 & 2000 & 4000 \\
\hline Cattle & 25 & 0.2 & 1.5 & 3 & 98.0 & 2000 & 4000 \\
\hline Sheep & 3.5 & 0.1 & 1.5 & 1.51 & 24.5 & 3250 & 7000 \\
\hline
\end{tabular}

Table 6: Livestock Live Weight, Growth Rate, and Meat Prices in 2018 (kilogram / Iraqi dinar)

\begin{tabular}{|c|c|c|c|c|c|c|c|c|}
\hline \multirow{2}{*}{ Animal } & \multirow{2}{*}{$\begin{array}{c}\text { Birth } \\
\text { Weight (kg) }\end{array}$} & \multirow{2}{*}{$\begin{array}{c}\text { Daily Growth Rate } \\
\text { (kg) }\end{array}$} & \multicolumn{2}{|c|}{ Daily Feed Consumption (kg) } & \multirow{2}{*}{$\begin{array}{c}\text { Market } \\
\text { Weight (kg) }\end{array}$} & $\begin{array}{c}\text { Price of Live } \\
\text { Weight } \\
\text { (ID/kg) }\end{array}$ & $\begin{array}{c}\text { Meat Price } \\
\text { (ID/kg) }\end{array}$ \\
\cline { 5 - 8 } & & Alfalfa & Bran & Straw & & & \\
\hline \hline Buffalo & 45.6 & $1.000-1.250$ & 3 & 3 & 5 & 450 & 8,000 & 14,000 \\
\hline Cattle & 41.5 & $0.535-0.750$ & 3 & 3 & 4 & 400 & 8,000 & 14,000 \\
\hline Sheep & 3.5 & $0.120-0.150$ & 1 & 0.5 & 1.5 & 26.2 & 9,000 & 16,000 \\
\hline
\end{tabular}

\section{Daily Milk Yields}

IMRP found that daily milk yields for buffalo varied within the marshlands. Yields in 2004 ranged from about seven kilograms in Huwaizah and five in Hammar and Al Chebayish / Central marsh, to ten in Nahr Al Aaz. The difference was possibly due to the fact that the forage and feed for buffalo were more abundant in Nahr Al Aaz than elsewhere. In the marshes, where the daily yields were low, and with only 150 lactation days per year, the annual yield was between 750 and 1070 kilograms. This compares negatively with the annual milk yield of 1342 kilograms recorded in Iraq outside the marshlands [16]. The average annual milk yield was 32 to $46 \%$ higher than what IMRP had found in the marshes at essentially the same time.

Buffalo milk yields in the marshlands have improved since then. Daily milk yields are roughly the same in Maysan, Dhi-Qar, and Basra areas where IMRP worked. And all three show a similar, steady increase of almost $2 \%$ from 2012 to 2017 . These yields would place the buffalo daily milk production in the marshes highly ranked in the world, but still well below Italian buffalo that produce up to 18 kilograms of milk daily.
Interestingly and unfortunately, Nahr Al Aaz, which was recorded with the highest daily milk production in 2004 , is suffering from a severe water shortage. Many inhabitants have left the area and moved to the vicinity of Al Chebayish on the edge of Central marsh in DhiQar governorate where water is more plentiful. Previously, Nahr Al Aaz was heavily populated by marsh dwellers, who owned large herds.

The data presented in Table $\mathbf{7}$ and Figure $\mathbf{4}$ were provided by the agricultural offices in the three governorates and in interviews conducted by staff of the College of Agriculture in the University of Basra between 2012 and 2017. These research sites included areas in or near the marshes where alfalfa and sorghum were detected by IMRP in 2004, such as Al Adil in Maysan governorate, which has a high concentration of the two crops.

\section{Lactation or Milking Period}

In 2006, IMRP found that the lactation or milking period for water buffalo in the marshlands was 150 days [16]. This compares unfavorably with the lactation period of 255 days recorded in Iraq outside the

Table 7: Daily Milk Yield of Buffalo from Marsh in Different Provinces (kilogram)

\begin{tabular}{|c|c|c|c|c|c|c|}
\hline Governorate & 2012 & 2013 & 2014 & 2015 & 2016 & 2017 \\
\hline Basra & 8.21 & 8.35 & 8.47 & 8.62 & 8.77 & 8.96 \\
\hline Maysan & 9.22 & 9.33 & 9.54 & 9.67 & 9.87 & 10.00 \\
\hline Dhi-Qar & 9.00 & 9.22 & 9.45 & 9.68 & 9.89 & 10.10 \\
\hline Mean & 8.81 & 8.97 & 9.15 & 9.32 & 9.51 & 9.69 \\
\hline
\end{tabular}




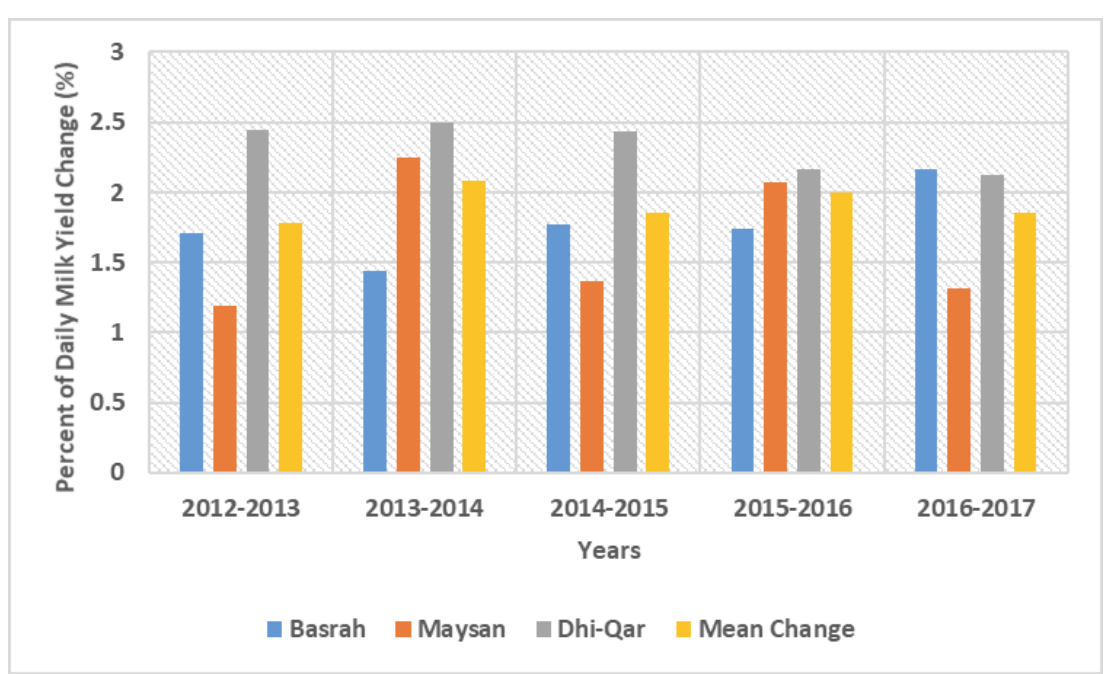

Figure 4: Daily Buffalo Milk Yield Change in the Southern Governorates (Percent of kilogram change).

marshlands [17]. The lactation period elsewhere in Iraq was 255 days or $70 \%$ higher than in the marshes [18].

In 2018, the annual lactation period for water buffalo in the three southern governorates was 237 or 238 days, with an increase of $58 \%$ during the past 12 years. Table 8 indicates that this increase has been incremental, with small but steady increases of one to four days from year to year between 2012 and 2017. This would mean a roughly 90 kilogram increase in milk production per lactation period for each buffalo. As the length of the lactation period is closely tied to the quality of feed and health of the animal, we think it is fair to conclude that the expansion of alfalfa and sorghum cultivation in the marshlands is at least partly, if not greatly, responsible, for the change.

Table 8: Lactation Period of Marshland Buffalo in the Southern Governorates (day)

\begin{tabular}{|c|c|c|c|c|c|c|c|}
\hline Governorate & 2006 & 2012 & 2013 & 2014 & 2015 & 2016 & 2017 \\
\hline Basra & & 227 & 230 & 231 & 232 & 234 & 238 \\
\hline Maysan & & 228 & 231 & 231 & 233 & 235 & 237 \\
\hline Dhi-Qar & & 227 & 231 & 232 & 234 & 234 & 237 \\
\hline Mean & 150 & 227 & 230 & 231 & 232 & 234 & 238 \\
\hline
\end{tabular}

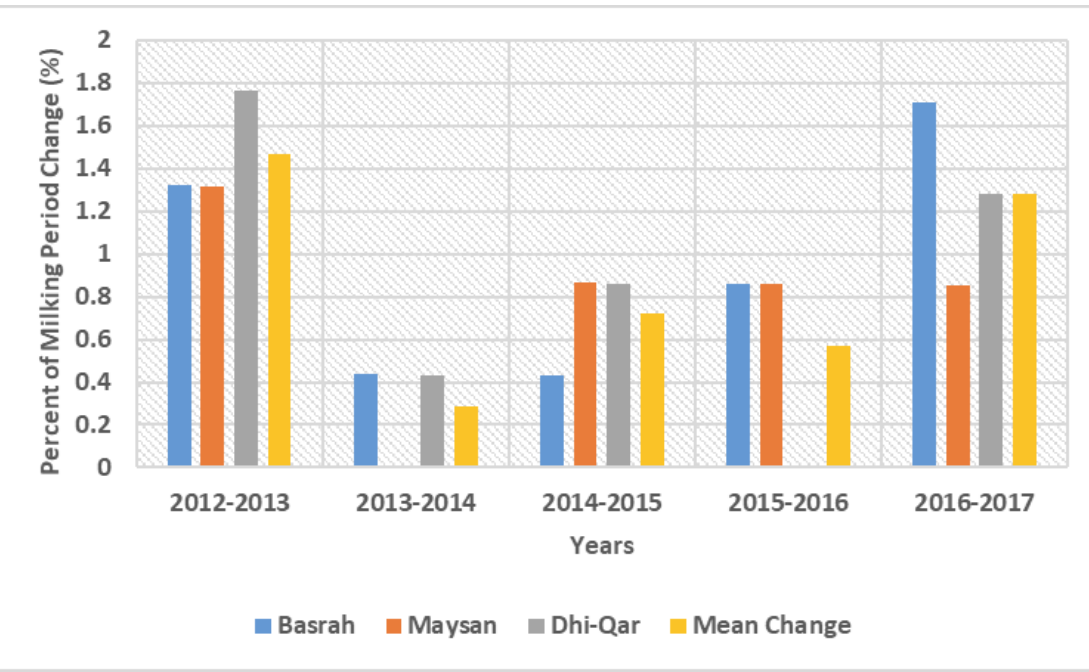

Figure 5: Percentage of Lactation Period Change for Water Buffalo. 
Table 9: Annual Milk Yields of Buffalo in Southern Governorates (kilogram)

\begin{tabular}{|c|c|c|c|c|c|}
\hline Governorate & $\mathbf{2 0 1 2}$ & $\mathbf{2 0 1 3}$ & $\mathbf{2 0 1 4}$ & $\mathbf{2 0 1 5}$ & $\mathbf{2 0 1 6}$ \\
\hline \hline Basra & 1863.67 & 1920.50 & 1956.57 & 1999.84 & 2052.18 \\
\hline Maysan & 2102.16 & 2155.23 & 2203.74 & 2253.11 & 2319.45 \\
\hline Dhi-Qar & 2043.00 & 2129.82 & 2192.40 & 2265.12 & 2314.26 \\
\hline Mean & 1999.87 & 2063.10 & 2113.65 & 2162.24 & 225.34 \\
\hline
\end{tabular}

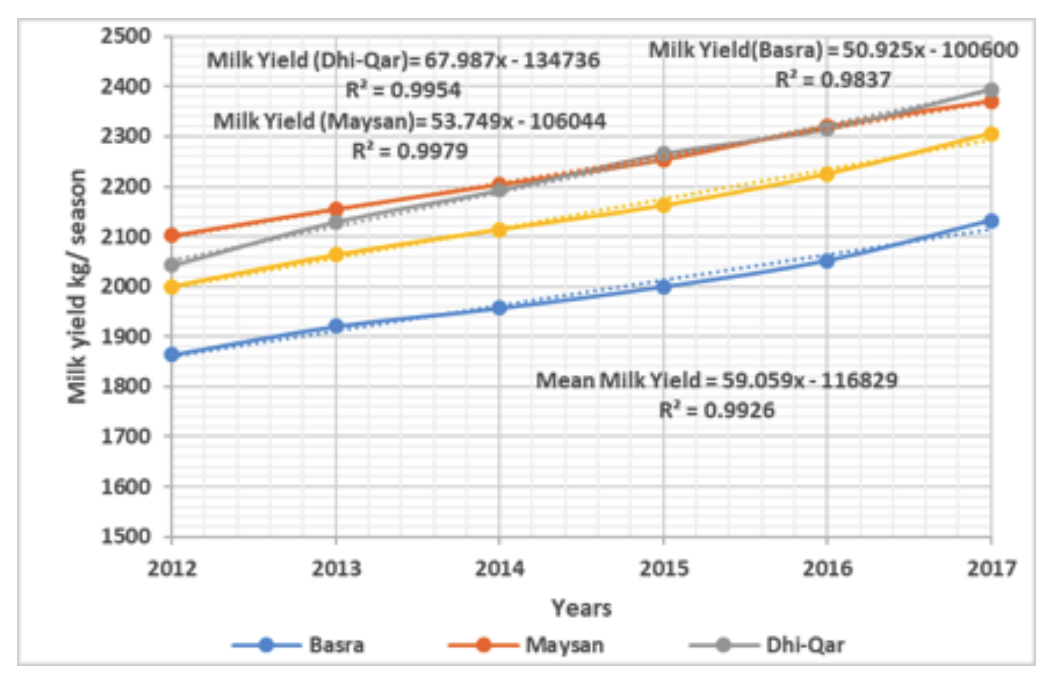

Figure 6: Trend of Milk Yield during 2012-2017 (kilogram).

\section{Total Annual Milk Yield}

When calculating milk yields over the lactation period, we found a steady increase from 2012 to 2017. Regression analysis was used to determine the association of yield and time. Our data showed a very accurate predictive rate of $99 \%$, which can be used to evaluate different plans to improve buffalo milk production.

The three governorates all experienced a linear increase in milk yield over the period: 50.9 kilograms in Basra, 53.7 kilograms in Maysan, and 67.98 kilograms in Dhi-Qar. The overall average increase in milk yield was 59.05 kilograms. This increase suggests a dynamic improvement in milk yields in the marshlands, which we believe can be attributed in part to IMRP's initiatives 12 to 14 years earlier when alfalfa and sorghum were first introduced into the area.

\section{Financial Benefits}

In calculating the monetary benefit of milk production improvement, the price of one kilogram of raw milk is about USD 1.25. The net profit from selling of each buffalo every year is about USD74 (59.05-

Table 10: Estimated Daily Gross Income, Costs, and Net Profits from Dairy Production

\begin{tabular}{|c|c|c|c|}
\hline Dairy Product & Quantity $\mathbf{( k g )}$ & Unit Price (USD) & Income and Costs (USD) \\
\hline \hline Cheese & 47.0 & 5.6 & 263.20 \\
\hline Yoghurt & 364.0 & 2.0 & 728.00 \\
\hline Cream & 10.5 & 11.2 & 117.60 \\
\hline Milk & 25.0 & 1.25 & 31.25 \\
\hline \multicolumn{2}{|c|}{ Uaily gross income based on 750 kilograms of milk } & USD 900 \\
\hline \multicolumn{2}{|r|}{ Estimated daily costs } & USD 240 \\
\hline \multicolumn{2}{|r|}{ Estimated net profit } \\
\hline
\end{tabular}


kilogram $x$ USD 1.25= USD 73.82). The total profit will depend on the number of buffalos kept by each breeder. The number of animals per herd has also increased dramatically since IMRP closed in 2006.

Table 10 calculates daily gross income of a smallscale commercial dairy industry on the margins of the marshes in Bayt Wafi of USD 1,140 from dairy products using 750 kilograms of raw milk. One operator estimated that her production costs, including producing her own milk or buying it from others, transportation, labor, shop, equipment and running costs, were about USD 900. That leaves about USD 240 net profit.

\section{ACKNOWLGEMENTS}

The authors would like to thank DAI in Bethesda, Maryland, USA, for providing generous financial support for the research and analysis. We also acknowledge the assistance provided by agricultural department staff in the three southern governorates who provided data and helped contact animal owners who were uniformly collaborative and generous in their dealings with us. We also single out Um-Haider of Bayt Wafi who provided essential data about her small-scale dairy operation.

\section{REFERENCES}

[1] Al-Fartosi K, Al-Saedy J. Mesopotamian Buffaloes (The Origin). Journal of Buffalo Newsletter 2013; 28: 25-30.

[2] Richardson CJ, Hussain NA. Restoring the Garden of Eden: An ecological assessment of the Marshes of Iraq. Bioscience 2011; 56: 477-489. https://doi.org/10.1641/00063568(2006)56[477:RTGOEA]2.0.CO;2

[3] Magid SA, Al-Murrani WK, Alkas JI. Iraq: Country Report, Animal Genetic Resources. Ministry of Agriculture, Baghdad, Iraq 2003.

[4] Al-Saedy JKM. Mesopotamian Buffaloes: The Origin. Journal of Buffalo Science 2014; 3: 30-33. https://doi.org/10.6000/1927-520X.2014.03.01.6
[5] Al-Saedy JKM. Iraqi Buffalo Now. Italian Journal of Animal Science 2007; 6: 1234-36. https://doi.org/10.4081/ijas.2007.s2.1234

[6] USAID (U.S. Agency for International Development). Reestablish Livestock and Dairy Production. 2004 Retrieved from http://www.iraqmarshes.org/activities/livestock.htm.

[7] Fazaa NA. Interim Draft Report on Water Buffalo in Chubayish, Nature Iraq 2007; 1-9. (http://citeseerx.ist.psu.edu/viewdoc/download?doi=10.1.1.50 5.6107\&rep=rep1\&type=pdf)

[8] Abu Tabeekh MA, Maktoof AS, Abdul Mohsen AM. Solutions or alternatives to protect livestock, especially buffalo from the risk of drought in Basra Governorate. Canadian Journal of Agriculture and Crops 2017; 2(2): 84-89. https://doi.org/10.20448/803.2.2.84.89

[9] Lindsay JA, Mason GWJ, Toleman MA. Supplementation of Pregnant Cows with Protected Proteins when Fed Tropical Forage Diets. Proceedings of the Australian Society of Animal Production 1982; 14: 67-78.

[10] Waghorn GC, Smith JF, Ulyatt MJ. Effect of Protein and Energy Intake on Digestion and Nitrogen Metabolism. In Wethers and Ovulation in Ewes. Animal Production 1990; 51 : 291-300. https://doi.org/10.1017/S0003356100005444

[11] Hinch GN, Davis GH, Crosbie SF, Kelly RW, Trotter RW. Causes of Lamb Mortality in Two Highly Prolific Booroola Crossbred Flocks and a Romney Flock. Animal Reproductive Science 1986; 12: 47-61. https://doi.org/10.1016/0378-4320(86)90016-3

[12] Stephenson RCA, Edwards JC, Hopkins PS. The use of urea to improve milk yield and lamb survival of Merinos in a dry tropical environment. Australian Journal of Agricultural Research 1981; 32: 497-509.

https://doi.org/10.1071/AR9810497

[13] Lynch JJ, Leng RA, Hinch GN, Nolan JV, Bindon BM, Piper LR. Effects of Cottonseed Supplementation on Birthweights and Survival of Lambs from a Range of Litter Sizes. Australian Society of Animal Production 1990; 18: 516.

[14] Saadullah M. Studies on Utilization of Rice Straw by Cattle. $\mathrm{Ph}$. D. Thesis. Royal Veterinary University, Copenhagen 1984.

[15] Preston TR, Leng RA. Matching Livestock Systems to Available Feed Resources. Asian Livestock 1987; 10(12): 158-163.

[16] Reiss P, Farhan A, editors. Iraq Marshlands Restoration Program: Final Report; DAI for the U.S. Agency for International Development. Bethesda, Maryland 2006.

[17] Ståhl Högberg M, Lind O. Buffalo Milk Production 2003; (www.milkproduction.com)

[18] Hussain NA, Reiss P. Exploring Program Sustainability and Impact Twelve Years Later: USAID Iraq Marshlands Restoration Program (IMRP). DAI, Bethesda, Maryland 2018.

\section{DOI: https://doi.org/10.6000/1927-520X.2019.08.02.1}

(c) 2019 Ayied and Reiss; Licensee Lifescience Global.

This is an open access article licensed under the terms of the Creative Commons Attribution Non-Commercial License (http://creativecommons.org/licenses/by-nc/3.0/) which permits unrestricted, non-commercial use, distribution and reproduction in any medium, provided the work is properly cited. 